\title{
Primary education quality in francophone Sub-Saharan Africa: determinants of learning achievement and efficiency considerations
}

\author{
Michaelowa, Katharina
}

\begin{abstract}
What are the most efficient means to ensure basic learning competencies for a high number of children? This question is analyzed on the basis of the exceptionally rich data set provided by the "Program on the Analysis of Education Systems" (PASEC), standardized and comparable for the five countries Burkina Faso, Cameroon, Côte d'Ivoire, Madagascar and Senegal. A Hierarchical Linear Model (HLM) is used to assess the individual, school level, and national characteristics determining fifth-grade students' achievement in French and mathematics. Special consideration is given to institutional factors. A further question addressed is the possibility of a tradeoff between enrollment and education quality.
\end{abstract}

DOI: https://doi.org/10.1016/s0305-750x(01)00061-4

Posted at the Zurich Open Repository and Archive, University of Zurich ZORA URL: https://doi.org/10.5167/uzh-172356

Journal Article

Accepted Version

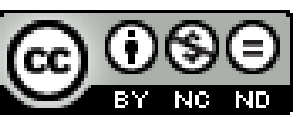

The following work is licensed under a Creative Commons: Attribution-NonCommercial-NoDerivatives 4.0 International (CC BY-NC-ND 4.0) License.

Originally published at:

Michaelowa, Katharina (2001). Primary education quality in francophone Sub-Saharan Africa: determinants of learning achievement and efficiency considerations. World Development, 29(10):1699-1716.

DOI: https://doi.org/10.1016/s0305-750x(01)00061-4 


\title{
Primary Education Quality in Francophone Sub-Saharan Africa:
}

\section{Determinants of Learning Achievement and Efficiency Considerations}

\author{
by \\ Katharina Michaelowa, Hamburg Institute of International Economics (HWWA) ${ }^{1}$ \\ (a revised version will be published in: World Development (October 2001 issue) Vol. 29, No. 10)
}

\section{SUMMARY}

What are the most efficient means to ensure basic learning competencies for a high number of children? This question is analyzed on the basis of the exceptionally rich data set provided by the "Program on the Analysis of Education Systems" (PASEC), standardized and comparable for the five countries Burkina Faso, Cameroon, Côte d'Ivoire, Madagascar and Senegal. A Hierarchical Linear Model (HLM) is used to assess the individual, school level, and national characteristics determining fifth grade students' achievement in French and mathematics. Special consideration is given to institutional factors. A further question addressed is the possibility of a trade-off between enrolment and education quality.

\footnotetext{
${ }^{1}$ The author would like to thank Paul Coustère and Luc Beghagel of the PASEC technical team, Dakar, for giving her access to the PASEC data set and for their help with the interpretation of the data. She would also like to thank Christian Morrisson for having guided this work, from the beginning, with many useful suggestions, as well as JeanMarc Bernard, Ulrich Hiemenz, Marcello Soto and Kristen Neymark for all their helpful comments. This work was started at the OECD Development Centre while the author was a staff member of this institution.
} 


\section{Introduction}

During the 1970s and 1980s most policy makers concerned with education in developing countries limited their attention to enrolment rates. Over the years, however, it became clear that access to school was not sufficient to ensure a decent level of basic learning. Although the gains in enrolment had been impressive in many parts of the world, including sub-Saharan Africa, low quality and high drop-out rates led to the deceptive result that many of the children left school again without having obtained a sustainable level of basic reading, writing and numeracy skills. The rising concern with education quality was strongly reflected in the protocols of the World Conference on Education for All in Jomptien, Thailand (1990) and the World Education Forum in Dakar, Senegal (2000). Ensuring education quality is a necessary complement to enrolment: quality and quantity have to go hand in hand.

To evaluate education quality, the most obvious indicator is learning achievement. However, comparative analysis of learning achievement in developing countries has long been constrained by a lack of comparable data. For francophone Sub-Saharan Africa, this gap is now narrowed by a survey carried out in the framework of the "Program on the Analysis of Education Systems" (PASEC) managed under the authority of the conference of education ministers (CONFEMEN). ${ }^{1}$ The data are derived from a stratified random sample of classrooms at different grade levels of primary education. Standardized tests in math and French were administered in primary schools of the five countries Burkina Faso, Cameroon, Côte d'Ivoire, Madagascar and Senegal, together with a collection of information on the students' socio-economic background and school variables that were collected using both teacher and director questionnaires. For all tests considered here, in both French and mathematics, Cronbach's alpha, the numerical coefficient of reliability, is between $78 \%$ and $84 \%$. This shows a good inter-item consistency and a high probability that carrying out the same test again would lead to very similar results. 
Admittedly, the sample also has a few shortcomings. These are in particular: (i) inconsistencies concerning the inclusion or exclusion of private schools in the national samples, (ii) a considerable number of missing observations for variables, especially at the individual student's level, and (iii) inconvenient definitions of some of the variables making it difficult to construct meaningful indicators (such as for children's work at home, for family income or for school funding). There is also an omission of a few potentially interesting explanatory variables in the sample. In particular, the sample does not allow to draw any conclusions about the role of local languages as a medium of instruction (Naumann and Wolf 2001) or about teachers' income. Nevertheless, despite these shortcomings, the now available data represent an exceptionally rich and impressive set of information allowing an in-depth discussion of the determinants of education quality.

A detailed description of the data is provided by CONFEMEN (1999a). CONFEMEN (1999a and b) also provide some initial empirical analysis using OLS for individual country as well as pooled regressions. In this paper, the econometric methodology will be improved, additional variables will be tested, and the available information from the PASEC data set will be combined with some information on the national level to estimate a three-level hierarchical linear model of students' learning achievement. Making use of the cross-country standardization of variables, all five countries will be analyzed jointly. While, in some cases, the country-by-country results of CONFEMEN (1999a and b) show differences in the sign and significance of explanatory variables, no theoretical explanation can be given for these differences. They seem to be strongly influenced by noise, especially for those variables with very limited within-country variation, and the joint model seems to be more reliable due to the considerably higher number of observations. In the empirical analysis carried out here, country specific differences are taken care of separately both by country-specific explanatory variables and country-specific random effects. The results of this estimation will then allow a discussion of the efficiency of various measures at student, school and country level to improve education quality. 


\section{Education outcomes and educational efficiency:}

\section{an initial overview}

At the end of primary education, students should have achieved, in principle, a sustainable level of basic literacy and numeracy skills. In order to compare educational attainment at this stage, we will focus our attention on the result of fifth-graders. This is the last grade of primary education in Madagascar, and the second highest grade in the other four countries covered by the sample. For this grade level, the PASEC database contains information on learning achievement for between 2000 and 2500 children in about 100 primary schools in each of the five countries. The items selected for the tests were discussed among education specialists and members of the different education ministries in order to equally reflect the curricula in all countries. There is one major difference between Madagascar and the other countries concerning the language of instruction. While both math and French classes are taught in French in Burkina Faso, Cameroon, Côte d'Ivoire and Senegal from the very beginning of primary schooling, Madagascar initially uses its local language in mathematics. Only from the third grade onwards, French becomes the language of instruction for this subject. Concerning Cameroon, it should be noted that the country runs two parallel education systems, one in English and one in French. Only the francophone system is considered here.

Table 1 shows the country averages of student achievement in mathematics and French, and in both subjects combined. Results are shown in terms of the average percentage of correct answers in the PASEC tests for fifth graders.

There are significant differences between country averages, with the exception of Burkina Faso and Côte d'Ivoire, when both subjects are taken together. Cameroon obtains the best results for the combination of math and French, closely followed by Madagascar. Madagascar heads the list in mathematics while its results are considerably lower in French. In parts, this might reflect the higher 
importance of the local language as the medium of instruction for primary education in Madagascar. Conversely, students in Côte d'Ivoire score much better in French where the country ranks second, than in math where the country ranks forth. Senegal obtains the worst results in both subjects.

Table 1: Educational outcomes in mathematics and French, 1996 (1)

Burkina Faso Cameroon Côte d'Ivoire Madagascar Senegal

Average rate of correct

responses $\left(5^{\text {th }}\right.$ grade $)$

Mathematics

French

$46 \%(0.33 \%) \quad 50 \%(0.37 \%) \quad 40 \%(0.31 \%) \quad 58 \%(0.33 \%) \quad 38 \%(0.40 \%)$

Both subjects

$44 \%(0.33 \%) \quad 55 \%(0.39 \%) \quad 50 \%(0.35 \%) \quad 42 \%(0.34 \%) \quad 34 \%(0.40 \%)$

Minimum learning

$45 \%(0.30 \%) \quad 53 \%(0.34 \%) \quad 45 \%(0.29 \%) \quad 51 \%(0.31 \%) \quad 35 \%(0.39 \%)$

achievement, MLA

Share of children

$20 \%$

$59 \%$

$34 \%$

$25 \%$

$20 \%$

reaching MLA

$34 \%$

$77 \%$

$54 \%$

$33 \%$

$55 \%$

(1) Standard errors in parenthesis.

(2) For Madagascar, data are from 1998.

Sources: CONFEMEN (1999a), UNESCO (1998), Michaelowa (2000).

Recognizing that the objective of education policy should not be quality alone, enrolment has to be considered as well. A special indicator is introduced in order to present education quality and enrolment simultaneously. This indicator shows the probability that any child in the country reaches a specific threshold of basic learning competencies. The threshold is set at the level of a minimum of $40 \%$ of correct answers in the PASEC test for fifth graders. The choice of this particular cut-off point is subjective, but motivated by the fact that the PASEC questionnaires are to a large extent based on multiple choice questions which would lead to almost $30 \%$ of correct answers even if answers were given at random. The indicator is calculated by multiplying the share of children above this threshold of minimum learning competencies by national fifth grade enrolment rates.

According to this indicator, Cameroon reinforces its leading position, combining a relatively high level of learning achievement with high enrolment rates. A child in this country has a chance of almost $60 \%$ to reach the minimum level of basic learning competencies as defined above. Madagascar, however, falls back to a medium position as soon as the quantitative aspect is taken 
into account. Its children have only a $25 \%$ chance to reach this level. It is interesting to note that this is not due to a particularly low initial primary enrolment, but to extremely high drop-out rates which then lead to a very low enrolment at fifth grade level (UNESCO, 1998). Due to considerably higher enrolment rates, Côte d'Ivoire obtains a much better result of 34\%, while Burkina Faso and Senegal share the last position with $20 \%$ each.

One could now suppose that these strongly differing results are mainly induced by the amount of financial resources a country chooses to invest into its education system. Figure 1 relates the percentage rates of minimum learning achievement (MLA) to average public expenditure for primary education during the previous decade (1985-1995). For two reasons the choice of this period appears to be more adequate than the choice of a single year: First, education expenditure can vary considerably between different years due to large investments which are not carried out on a regular basis. Second, one cannot always expect the effects of education spending to be immediate.

\section{Figure 1 : The efficiency of education spending}

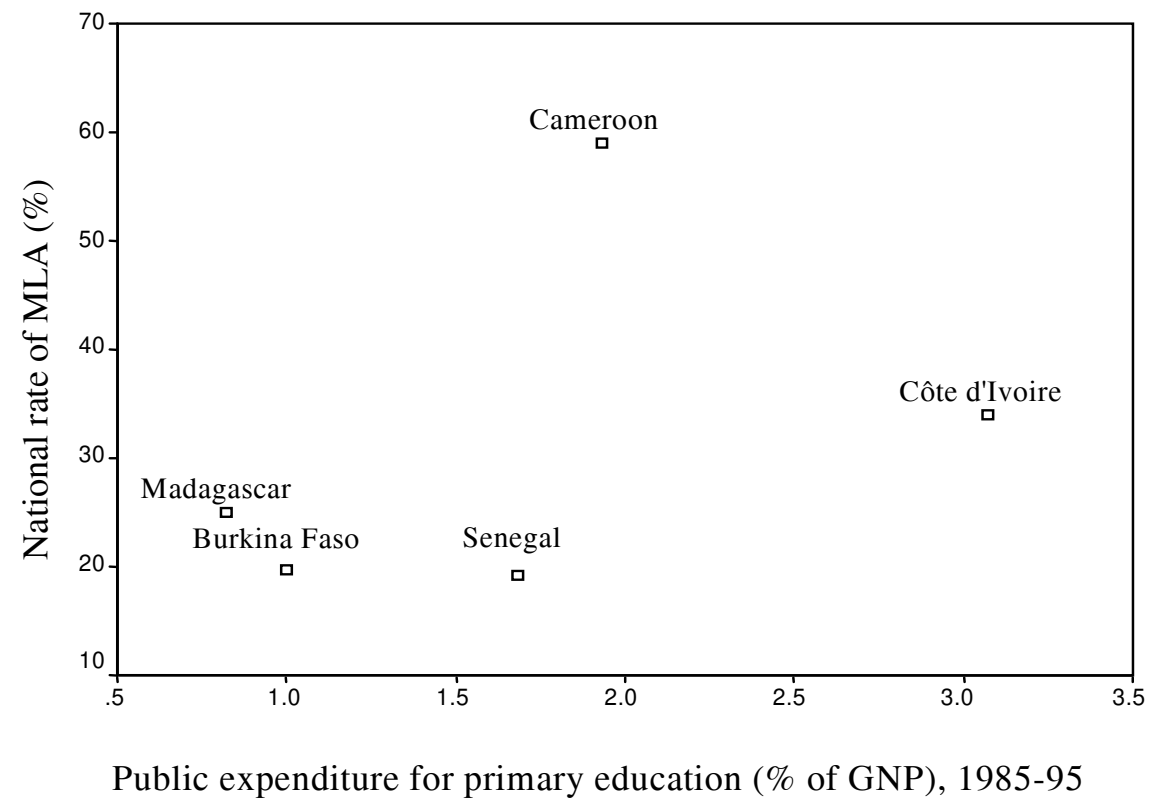

Figure 1 illustrates that Cameroon obtains its high rate of MLA with moderate expenditure. Côte d'Ivoire spends nearly twice the amount of Cameroon, with clearly inferior results. Senegal and 
Burkina Faso share the last position with respect to the rate of MLA, but while Senegal's expenditure is almost as high as Cameroon's, primary education expenditure in Burkina Faso is much lower. Madagascar, finally, spends even less, but with results slightly exceeding those of both Senegal and Burkina Faso.

It becomes clear that the relationship between primary education expenditure and educational outcomes is not straightforward. Apparently, financial resources are much more efficiently used in some countries than in others. At the higher end of education outcomes, Cameroon clearly predominates over Côte d'Ivoire, and at the lower end, Madagascar and Burkina Faso clearly rank above Senegal in terms of efficiency. These efficiency positions depend on various political, economic, social, geographic and cultural factors. An initial overview about selected general background factors of the national education systems is presented in Table 2.

Table 2: Background factors of national education systems, 1995

\begin{tabular}{|c|c|c|c|c|c|}
\hline & Burkina Faso & Cameroon & Côte d'Ivoire & Madagascar & Senegal \\
\hline \multicolumn{6}{|c|}{ General background factors: } \\
\hline $\begin{array}{l}\text { Adult illiteracy } \\
\text { (Illiteracy rate 1975) }\end{array}$ & $91 \%$ & $61 \%$ & $81 \%$ & $60 \%$ & $82 \%$ \\
\hline $\begin{array}{l}\text { Spread of French (\% of } \\
5^{\text {th }} \text { graders speaking } \\
\text { French at home) }\end{array}$ & $34 \%$ & $51 \%$ & $38 \%$ & $12 \%$ & $16 \%$ \\
\hline $\begin{array}{l}\text { Urbanization (urban } \\
\text { population in \% of total) }\end{array}$ & $15.9 \%$ & $44.7 \%$ & $43.3 \%$ & $26.5 \%$ & $43.8 \%$ \\
\hline \multicolumn{6}{|l|}{ Standard of living : } \\
\hline GNP per capita (PPP) & 234 US\$ & 564 US\$ & 666 US\$ & 225 US\$ & $521 \mathrm{US} \$$ \\
\hline $\begin{array}{l}\text { Average possession of } \\
\text { radio and television by } \\
\text { families of } 5^{\text {th }} \text { graders } \\
\text { (possessing both }=2, \\
\text { none }=0 \text { ) }\end{array}$ & 1.02 & 1.45 & 1.30 & 1.20 & 1.51 \\
\hline $\begin{array}{l}\text { Average number of } \\
\text { regular main meals (out } \\
\text { of three) for } 5^{\text {th }} \text { graders }\end{array}$ & 2.48 & 1.90 & 2.44 & 2.51 & 2.74 \\
\hline \multicolumn{6}{|l|}{ Primary school system } \\
\hline $\begin{array}{l}\% \text { of } 5^{\text {th }} \text { graders } \\
\text { currently repeating their } \\
\text { class }\end{array}$ & $15 \%$ & $31 \%$ & $27 \%$ & $39 \%$ & $21 \%$ \\
\hline $\begin{array}{l}\text { Average number of } \\
\text { years per pupil to } \\
\text { successfully complete } \\
5^{\text {th }} \text { grade }\end{array}$ & 7.3 & 7.3 & 8.5 & 16.2 & 7.1 \\
\hline
\end{tabular}


A relatively high initial literacy level favors the education systems in Côte d'Ivoire and Madagascar, while the spread of French, important as one of the subjects tested and as the language of instruction, favors Cameroon followed by Côte d'Ivoire and Burkina Faso. Urbanization is comparatively low in Burkina Faso and Madagascar which might make it more difficult to efficiently provide educational infrastructure. GNP per capita (PPP) is more than twice as high in Côte d'Ivoire, Cameroon and Senegal as in Burkina Faso and Madagascar. At the level of fifth grade students, this is reflected in the greater spread of radio and television sets in individual families. The correlation is not very strong, however, and even less so, when GNP per capita is compared to the average number of fifth graders' regular meals. While the average number of meals is reasonably high in Madagascar, it is very low in Cameroon. The reason might be that countries succeed to a very different extent to attract poor children into the school system and to prevent their early drop-out. In Madagascar, general child malnutrition according to anthropometric measures is extremely high (Morrisson, Guilmeau and Linskens 2000, p. 18f.). At the same time, the country suffers from particularly high drop-out rates. If the poorest drop out, pupils nutritional status at the end of primary education will necessarily look rather favorable. The average number of years per pupil to successfully complete fifth grade accounts for both repetition and drop-out. It clearly shows that the situation in Madagascar is particularly problematic. On average, it takes 16.2 years until one student successfully completes five years of schooling. Both repetition and drop-out are very high as compared to the other four countries. As compared to countries in non-francophone Africa and other regions of the world, repetition rates are extremely high for all countries in the sample.

The relative impact of these and other factors will be discussed in a more structured way in the following sections. In particular, it can be asked to which extent differences in the efficiency of education spending depend on:

(a) The context and initial conditions the education system is currently facing (e.g. adult literacy, use of language of instruction by parents, overall economic development). 
(b)The mix of educational inputs.

(c)The capacity to transform a given input mix at given cost into effective student learning (depending, in particular, on the institutional setting).

(d)The cost of educational input factors (such as, in particular, teacher salaries).

While the factors under (a) have to be considered as given constraints, linked to a particular national setting which cannot be changed, others can be influenced by policy decisions. It is important to identify the latter, in order to increase children's chances to attain a minimum level of basic literacy and numeracy skills.

\section{Determinants of education quality}

Econometric analysis on the basis of the PASEC data allows the different factors influencing students' achievement to be distinguished, and their individual effects to be estimated. The initial selection of explanatory variables is based on the standard choice of variables for estimations of so called "education production functions"2 adapted to the availability of data in the PASEC database. It also benefited from the initial analysis of the data by CONFEMEN (1999c,d,e,f). It should be noted that variables considered here are not only "inputs" in the narrow sense of the word. They include indicators of the institutional setting and country specific initial conditions of the education system, in order to cover the four major reasons for country differences in efficiency listed above.

Sources of variance are at three different levels: student, school / class ${ }^{3}$ and country level. Variance decomposition using a simple variance components model (see e.g. Lockheed and Longford 1990, p.22f.) gives some insight into the variance to be explained at each of these levels. The bulk of the variance is at the individual student's level (81\%), but at class level $(13 \%)$ and national level (6\%), the variance is not negligible either. Correspondingly, variables include data on three different levels of aggregation: (1) students' individual characteristics and socio-economic characteristics of their families, (2) school, classroom and teacher characteristics, and (3) national background 
characteristics. The inclusion of variables of different levels of aggregation imply a nested data structure whereby students can be grouped within schools and schools within countries. In order to adjust to this particular data structure, econometric analysis is carried out in the framework of a three-level Hierarchical Linear Model (HLM).

For two reasons this approach is preferable to Ordinary Least Squares (OLS): First, HLM allows links between different levels to be analyzed. This feature will be used here to examine the effect of school-level variables on differences in learning between boys and girls. Second, OLS estimation is inappropriate because the underlying assumption of independent observations is violated. Since the same school- and country-level information is used for each student within a given school or country, observations obviously depend on each other. While OLS coefficient estimates remain consistent, their estimation is not efficient and t-statistics will be misleading due to inconsistent estimations of the variance. Using HLM avoids pooling information from different levels of aggregation, clarifies the data structure and the corresponding structure of the error term, and thereby paves the way for appropriate estimation techniques.

The structure of the three-level HLM for $\mathrm{i}=1, \ldots, \mathrm{N}_{\mathrm{jl}}$ students in $\mathrm{j}=1, \ldots, \mathrm{J}_{1}$ schools and $1=1, \ldots, \mathrm{L}$ countries, is as follows:

Level 1 (students): $\quad \mathrm{y}_{\mathrm{ijl}}=\mathrm{Z}_{\mathrm{ijl}} \alpha+\mathrm{X}_{\mathrm{ijl}} \beta_{\mathrm{j} 1}+\mathrm{r}_{\mathrm{ijl}}$

Level 2 (schools): $\quad \beta_{\mathrm{jl}}=\mathrm{B}_{\mathrm{jl}} \rho+\mathrm{W}_{\mathrm{jl}} \gamma_{1}+\mathrm{u}_{\mathrm{jl}}$

Level 3 (countries): $\quad \gamma_{1}=\mathrm{O}_{1} \xi+\mathrm{v}_{1}$

Learning achievement of student $\mathrm{i}$ at school $\mathrm{j}$ in country 1 is represented by $\mathrm{y}_{\mathrm{ij}}$. The vectors $\alpha, \rho$ and $\xi$ are fixed coefficients which do not vary across groups. $\mathrm{Z}_{\mathrm{ijl}}, \mathrm{B}_{\mathrm{j} 1}$ and $\mathrm{O}_{1}$ are the corresponding data matrices. The vectors $\beta_{\mathrm{j} 1}$ and $\gamma_{1}$ are random coefficients. They vary across groups (schools or countries respectively) and are explained by an equation on the subsequent level. In the context of our analysis, $\beta_{\mathrm{jl}}$ has two components : a school-specific constant, and a school-specific measure of the effect of gender on student achievement (for each school $\mathrm{j}$ in each country 1 ). This means that 
there are actually two equations at level 2 : In the first, school- or class specific factors are used to explain the school-specific constant, and in the second, school- or class-specific factors are used to explain gender differences in learning. The link between level 2 and level 3 is kept onedimensional. The random coefficient $\gamma_{1}$ only represents a country-specific constant which is explained by country-specific variables at level 3. The corresponding data matrices for $\beta_{\mathrm{j} 1}$ and $\gamma_{1}$ are $\mathrm{X}_{\mathrm{ij} 1}$ and $\mathrm{W}_{\mathrm{j} 1}$ respectively. ${ }^{4}$

Finally, $\mathrm{r}_{\mathrm{ij}}$, $\mathrm{u}_{\mathrm{jl}}$ and $\mathrm{v}_{\mathrm{l}}$ represent the residuals (random effects) at the different levels. It is assumed that they have zero mean and that they are uncorrelated among each other and across different $\mathrm{i}, \mathrm{j}$ or 1. It is further assumed that neither the variances of $r_{i j l}$ and $v_{l}$, nor the variance-covariance matrix of the vector $\mathrm{u}_{\mathrm{j} 1}$ depend on $\mathrm{i}, \mathrm{j}$ or 1 . These assumptions are rather strong, implying, in particular, that random and fixed components are uncorrelated, an assumption that also excludes the possibility of random components picking up the effect of omitted variables correlated to the fixed regressors.

Substituting the higher level equations for the corresponding coefficients on the preceding level, we obtain the reduced form of the model, expressing student achievement in terms of explanatory variables from all three levels:

$$
\mathrm{y}_{\mathrm{ijl}}=\underbrace{\mathrm{Z}_{\mathrm{ijl}} \alpha+\mathrm{X}_{\mathrm{ijl}} \mathrm{B}_{\mathrm{jl}} \rho+\mathrm{X}_{\mathrm{ijl}} \mathrm{W}_{\mathrm{jl}} \mathrm{O}_{\mathrm{l}} \xi}_{\text {(fixed effects) }} \underbrace{\xi \mathrm{X}_{\mathrm{ijl}} \mathrm{W}_{\mathrm{jl}} \mathrm{v}_{\mathrm{l}}+\mathrm{X}_{\mathrm{ijl}} \mathrm{u}_{\mathrm{jl}}+\mathrm{r}_{\mathrm{ijl}}}_{\text {(random effects) }}
$$

Although strong assumptions were made concerning the random effects, the covariance of the overall error term is inevitably different from zero for two students of the same school (or in different schools but in the same country) as long as there is a positive variance between schools (or between countries): $:^{5}$ 


$$
\begin{aligned}
& \operatorname{Cov}\left(\left(X_{i j l} W_{j 1} v_{1}+X_{i j l} u_{j 1}+r_{i j l}\right),\left(X_{h j l} W_{j 1} v_{1}+X_{h j l} u_{j l}+r_{h j l}\right)\right) \\
& =E\left[\left(X_{i j l} W_{j 1} v_{1}+X_{i j l} u_{j 1}+r_{i j l}\right)\left(X_{h j l} W_{j 1} v_{1}+X_{h j l} u_{j l}+r_{h j l}\right)^{\prime}\right] \\
& =X_{i j l} W_{j 1} \operatorname{Var}\left(v_{1}\right) W_{j 1}, X_{h j l}+X_{i j l} \operatorname{Var}\left(u_{j l}\right) X_{h j l},
\end{aligned}
$$$$
, \quad \mathrm{i} \neq \mathrm{h}
$$

As long as the groups of the data set are balanced, i.e. with the same number of observations for each group of a given level, the model can be estimated using Generalized Least Squares (GLS). However, in the PASEC data base, groups are not balanced, and it becomes necessary to apply maximum likelihood estimation methods. The iterative procedure to carry out these estimations is programmed in GAUSS following the expectation-maximization (EM) algorithm described in the technical annex of Bryk, Raudenbush (1992). ${ }^{6}$

Estimation results for the fixed coefficients at all three levels are presented in Table 3 . The explained variable is the individual students' rate of correct answers in the PASEC tests in French and mathematics at the end of the fifth grade. Since it is intended to assess learning achievement during primary education as a whole, this variable was preferred to a measure of students' progress over the year. Obviously, the disadvantage of this choice is the probably less clear effect of certain school level variables, for which information only covers the most recent year. For instance, teachers might not be the same over the whole period of primary education, and children might change schools. However, if the initial results of students at the beginning of the fifth grade are corrected for, this variable will absorb parts of the characteristics of students and their families, which simultaneously determine learning outcomes at the beginning and at the end of the year. Similarly, national variables concern primary education as a whole and not just students' progress during a single year. Finally, PASEC tests at the beginning of the year are not directly comparable 


\section{Table 3: Determinants of education quality}

Explained variable $\left(\mathrm{y}_{\mathrm{ijl}}\right)$ : Share of correct answers in math and French combined

Regression (1): $\mathrm{N}=5775$, Regression (2): $\mathrm{N}=4909$

Individual level (level 1)

School level (level 2)

National level (level 3)

Intermediate variables (random coefficients) to be explained at this level:

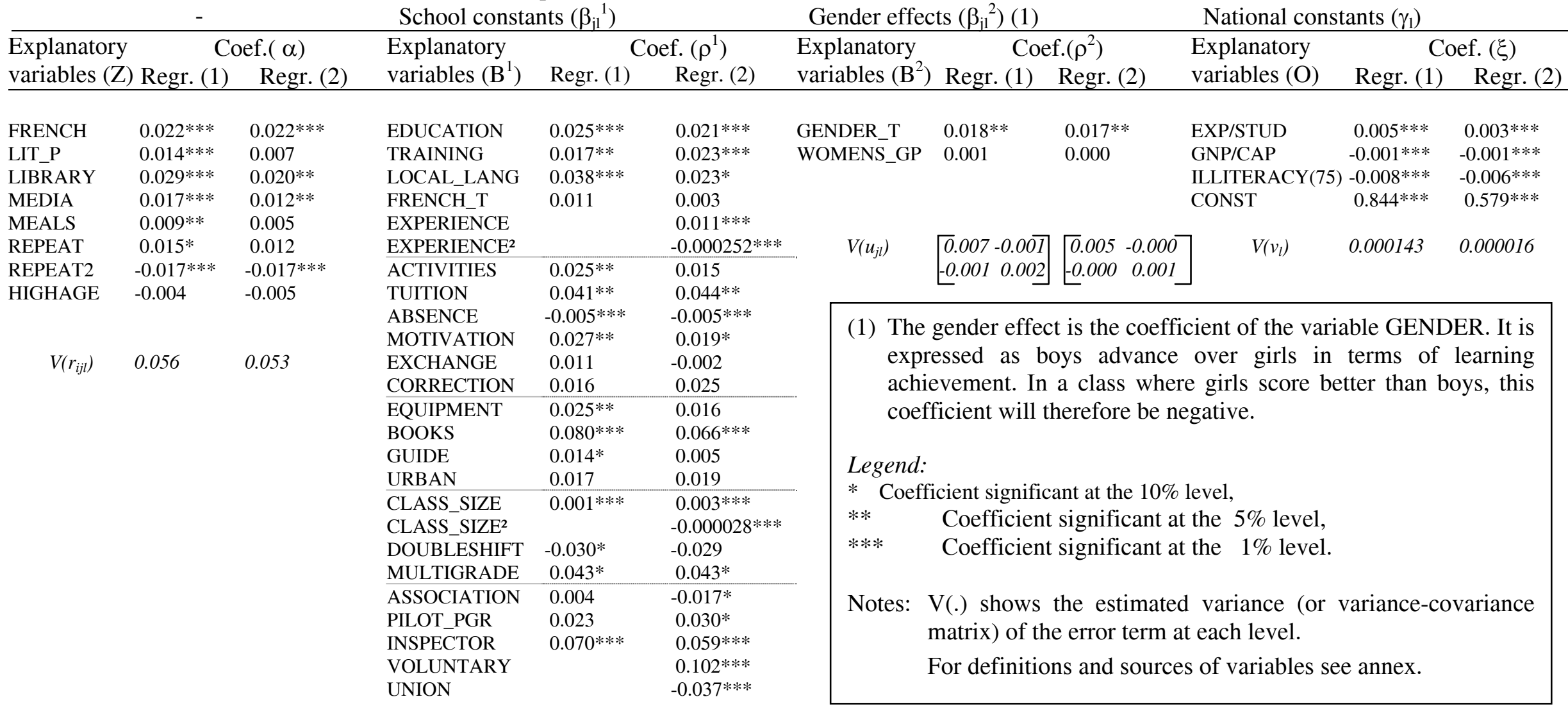


across all countries. Thus overall, the choice to use only the results of tests at the end of the fifth grade seems preferable.

(a) Student and family characteristics

The columns in Table 3 correspond to the four sub-equations of the model, one for level 1, two for level 2, and one for level 3. In each column, names of explanatory variables are followed by parameter estimates for two alternative regressions that differ in their level 2 specification.

The first column shows how individual student and family characteristics influence learning achievement. With one exception, all variables are significant in regression 1 . In regression 2 three variables fall under the $10 \%$ level of significance, but only slightly. It appears that students benefit from a French speaking family background (FRENCH) and from parents’ literacy (LIT_P). Besides a French speaking environment and parents' literacy, the availability of books (LIBRARY) and of radio and television (MEDIA) at home, and regular breakfast, lunch and dinner (MEALS) also show a positive influence on learning achievement. Books help to practice reading as well as spelling and grammar. Radio and television are an important source of information and can help the children to get used to the French language even if it is not used at home. Conversely, an undernourished child can have physical problems in following the classes and tends to be sick more often. The latter is suggested by findings of other studies based on anthropometric data for various developing countries [e.g. Harbinson and Hanushek (1992) for Brazil, Jamison (1986) for China, Moock and Leslie (1986) for Nepal, and Martorell and Habicht (1986)]. Attempts to capture a general effect of wealth separately by an index of other durable goods such as a car, a fridge and a video recorder have not led to significant results (Michaelowa 2000, p. 24). Unfortunately, data for more easily comparable measures such as family income or consumption expenditure are not available.

The remaining level 1 variables are particularly interesting given the extremely high repetition rates in francophone African countries. If a student repeats the current grade (REPEAT), this tends to give him, ceteris paribus, some advance on his classmates. However, if he or she repeats one or 
more classes before the current fifth grade level (REPEAT2), the test scores at the end of the fifth grade will be comparatively low. This shows that gains from grade repetition are only temporary. A PASEC study on grade repetition based on a panel of second grade students shows similar results (CONFEMEN, 1999g). The study even suggests that perceived initial benefits might be misleading: In many cases students would have progressed even more, if they had remained in their original class.

Results differ from PASEC and other studies concerning the estimated effect of students' age. CONFEMEN (1999c, p. 49 and 1999d, p. 58) and UNESCO/UNICEF (1995a, p. 32 and 35 , and 1995b, p. 48) find significantly lower test scores for relatively old students (HIGHAGE). The reason is that in none of these studies, repetition of lower grades is taken into account. Since age and repetition are highly correlated, the negative relationship between lower grade repetition and test scores is wrongly attributed to age.

(b) Teacher, classroom and school characteristics

Turning to the level 2 variables (Table 2, column 2), different types of variables can be distinguished. The first relate to the teacher and his own educational and motivational background. While the PASEC national studies (CONFEMEN, 1999f, p. 38), Michaelowa (2000) and studies for other countries (e.g. Tan, Lane and Coustère, 1997, p. 866 for the Philippines) test the impact of a dummy variable for high educational attainment (successful completion of at least upper secondary education) and do not find the expected positive and significant effect, a more precisely specified continuous variable is used here to measure teachers' level of educational attainment (EDUCATION). In this more precise specification, both teachers' initial education and regular training (TRAINING) appear to be important. Moreover, teachers' knowledge of the local language (LOCAL_LANG) has a positive and significant effect on pupils' learning. It might be important for linking up with students, parents and civil society. 
Surprisingly, teachers' knowledge of French (FRENCH_T), the language of instruction, has no significant effect. In other regression specifications with less precisely defined teacher education, this variable is highly significant. It might thus be that the subject knowledge measured by the education variable absorbs the effect of teachers' fluency in French.

Teaching experience (EXPERIENCE) is another variable whose measurable impact depends on the precise specification. In a linear specification, a clear effect is difficult to establish. Therefore it was left out in the first regression. In the second regression, however, it was introduced in a quadratic specification following Bernard's (1999a, p. 22) suggestion that initially, the effect might be positive while being negative thereafter. Results are highly significant and suggest an "optimal" experience of about 22 years.

Concerning teachers' non-school activities, their motivation and their absence from school, results are the following: Non-school activities such as farming or running a small business (ACTIVITIES) have a positive coefficient that is significant in regression 1 . Surprisingly, this indicates that if the teacher also works outside school, students' performance is generally better. This suggests that nonschool activities reflect the teachers' dynamics rather than to show to what extent their attention is diverted from teaching. Bernard (1999b, p. 17) describes the different activities taken into account. One specific activity analyzed separately here is private tuition (TUITION). The coefficient is equally positive and significant. This might simply reflect the fact that those children who attend the tuition score better because they spend more time with learning activities. In any case, it does not give much support to the argument (e.g. African Development Bank, 1998, p. 197) that teachers tend to focus all their effort and instruction material on the better paid private tuition so that overall, student achievement would decrease.

The number of days teachers are absent from school (ABSENCE), and teachers' self-reported job satisfaction (MOTIVATION) have significant coefficients of the expected negative and positive sign respectively. The impact of pedagogical features of teaching practice, however, cannot be 
identified since neither the exchange between teachers (EXCHANGE) nor the correction of students' written homework (CORRECTION) has a significant effect.

With respect to classroom equipment, the availability of books appears to be the most important factor. There is a strongly significant and positive impact of the availability of students' textbooks (BOOKS) on learning achievement. The coefficient shows that, ceteris paribus, students in a class where each child has a textbook in both French and mathematics, score 6.6 to 8 percentage points higher than students in a class with no books. A difference of 8 percentage points corresponds to almost $18 \%$ of mean scores. This underlines the importance of books already noted at the individual level. The availability of classroom equipment such as of banks and desks, a blackboard, chalk, and similar basic equipment (EQUIPMENT) as well as the availability of teachers' manuals (GUIDE) equally show a positive though somewhat less pronounced and less clearly significant effect. Other studies show similar results for different countries. In Ghana, for instance, Glewwe and Jacoby (1994, p. 858f.) find a positive impact of an increased number of blackboards, and of classroom repairs. Once these equipment factors are taken into account, the variable URBAN indicating whether the school is located in town or in a rural area, does not show any significant impact any more.

The following group of variables relates to class organization and management. Surprisingly, regression 1 shows a positive and significant effect of the number of students in each class (CLASS_SIZE) on student achievement. While one might agree that, at least below a certain limit, an increase in class size will not necessarily reduce student achievement (Hanushek, 1998, p. 20ff.; Mingat, Suchaut, p. 104ff.), an overall positive coefficient is difficult to explain. Regression 2 therefore uses an alternative quadratic specification which provides a more plausible picture of the impact of class size. The highly significant coefficient estimates indicate that, up to a class size of 62 pupils, additional students have indeed a (decreasing) positive effect on learning. From this number onwards, however, the effect becomes increasingly negative. Nevertheless, it is worth 
noting that within realistic class sizes, even in Africa, the effect remains rather modest. In a class of 80 pupils, ten additional students would lead to a reduction in achievement by only 1.25 percentage points. In the most extreme case, at the sample's maximum class size of 139 students, a further increase by ten students would lead to a reduction in achievement by 4.5 percentage points, i.e. by $10 \%$ of average achievement. Given this rather modest effect of high student numbers, there does not seem to be too much risk of a quality-quantity trade-off.

The variable DOUBLSHIFT indicates that two or three classes work in the same classroom, and generally with the same teacher, during different parts of the day. This is a tool to manage high numbers of students within a given framework of infrastructure and teaching staff, without increasing class size. The impact turns out to be significant (in regression 1 and just below significant in regression 2) and negative. CONFEMEN (1999f, p. 42) and Mingat, Suchaut (1998, p. 107) explain this effect by the reduced time devoted to each individual class in terms of teaching and correction of written assignments. At the same time, teaching children of different grade levels in the same class (MULTIGRADE) does not have any negative, but rather a significant positive effect. This strategy is generally used when student numbers are too small to create a separate class for each grade level. Although less time can be specifically devoted to students of each grade, teaching can be adjusted in a way to let students benefit across different grades. Examples in different countries during the 90 s equally show that multigrade teaching can be surprisingly successful (UNICEF, 1999, p. 34; Jarousse, Mingat, 1993).

The last group of explanatory variables relates to the link between the school, the school environment and other institutional factors. The effect of active school associations (ASSOCIATION) is not clear. Regression 2 suggests that the existence of active school committees involving external people (parents, public authorities etc.) has a rather negative effect, possibly because they detract teachers from their central task of teaching. Conversely, school participation in a special program such as a pilot project, partnership with a foreign school, or cooperation with an 
NGO (PILOT_PGR) reveals a positive effect which might be related to additional funding, but also to an exchange of ideas and the creative freedom to develop new ideas.

Another interesting variable is the visit of the school inspector (INSPECTOR). Students in schools visited by the inspector during the current year reach significantly higher scores than those in other schools. If inspectors hesitate to travel to remote areas, this kind of result could be the mere consequence of a deliberate selection of schools (Mosha, 1988, p. 37; CONFEMEN, 1999e, p.117). However, in the PASEC countries, the coefficient of correlation between a remote location of the school (2-hour minimum distance to the next town) and inspection is only -0.02 . Moreover, the location in terms of urban via rural is corrected for in the regression through the variable URBAN. The effect of INSPECTOR thus rather seems to be of a systematic institutional nature. In fact, the visit of the inspector means that some transparency is made concerning the teacher's effort on teaching. The inspector can also give feedback and encourage good teaching. In particular, the evaluation by the inspector is relevant for the individual teacher's advance on the salary scale. Thus, visit of inspectors creates an incentive for teachers to increase their teaching effort.

Given the strong effect of this variable, two more institutional and incentive related variables are introduced in regression 2. The first is a dummy variable indicating whether the teacher is a civil servant or a teacher engaged on a so called "voluntary" basis (VOLUNTARY) which generally implies significantly lower pay and a fixed term contract. In many cases, voluntary teachers are directly employed and paid by the pupils' parents. This implies a much higher level of direct responsibility towards the parents, and the need to perform well in order to be retained in the current position or to be promoted. Correspondingly, despite lower pay, the coefficient is positive, strongly significant and extremely high.

Finally, it is taken into account whether the teacher is member of a teachers' union. Wößmann (2000, p. 75f.) and Minter-Hoxby (1996) show the detrimental effect of teacher unions in OECD countries due to their impact on teachers' rent seeking behavior. While individual teachers share 
many objectives with their students and parents, in particular concerning successful learning achievement, union membership might tend to divert their effort towards those objectives that are commonly shared by all teachers, i.e. in particular, good pay and low working time. The regression for sub-Saharan African countries leads to a result in line with this hypothesis: On average, union membership is significantly and negatively related to student achievement.

The inclusion of these two additional institutional variables and the quadratic specifications of class size and teachers' experience in regression 2 reduces the variance of the corresponding residual $\mathrm{V}\left(\mathrm{u}_{\mathrm{jl}}{ }^{1}\right)$ by $2 / 7=29 \%$ which implies a considerable improvement of the explained level 2 variance with respect to regression 1 .

(c) Learning differences by gender

Column 3 in Table 2 considers school level variables with respect to gender specific learning. While a gender dummy introduced at level 1 of the regression does not reveal a significant difference between girls' and boys' overall learning achievement (Michaelowa 2000, p. 25), there might be clearer differences at the level of individual schools determined by school or class specific factors. The regression identifies teachers' sex (GENDER_T) as such a factor. The positive and significant coefficient indicates that girls' achievement will benefit from a female, and boys' achievement from a male teacher. On average, if the teacher is a man, the difference between the scores of girls and boys increases by 1.7 to 1.8 percentage points (i.e. $4 \%$ of average scores) in favor of the latter. Explanations for this result might be both, the teacher's role as a model for his or her students, and the often reported problems of sexual harassment in African schools (see e.g. Proteau 1998 for Côte d'Ivoire). Similar to the effect found here, Mingat and Suchaut (1998, p. 181f.) indicate a positive impact of female teachers on girls' enrolment and on decreased female drop-out rates. 
The second variable tested with respect to its potential influence on gender specific learning differences reflects the school's contact with women's groups (WOMENS_GP). This factor does not show any significant effect.

\section{(d) National characteristics}

Column 4 in Table 2 presents the level 3 effects on overall learning achievement. Regression results indicate a significant role of public primary education expenditure per student (EXP/STUD). The measure covers average expenditure from 1985 to 1995 . Since many variables accounting for unit cost have already been corrected for at level 2 of the regression, the remaining effect could be attributed to the different national cost of given factors. For instance, the effect might arise from a positive motivational impact of the level of teachers' salaries. Salaries account for the bulk of the funding and are not taken into account elsewhere in the regression. Even relative to GDP per capita, they vary greatly between countries. According to Mingat and Suchaut (1998, p. 78), the relation between primary teachers' salaries for 1990 and GDP per capita ranges from 2.6 in Cameroon, 3.0 in Madagascar, 6.2 in Côte d'Ivoire and 7.2 in Senegal, to 8.4 in Burkina Faso. However, including this variable directly into the regression instead of EXP/STUD, the corresponding coefficient turns negative. Michaelowa (2000, p. 35f.) does not find any significant positive result either. ${ }^{7}$ This effect is puzzling since it is difficult to explain the positive coefficient of EXP/STUD by anything else. At best, one might suggest that the number of schools could play an important role. School construction does not only give access to education for a higher number of children, but also reduces the distance to school for those who are enrolled. As shown by Tansel $(1997$, p. $840 \mathrm{f}$.) for Côte d'Ivoire and Ghana, the latter can have significant effects on learning achievement. Unfortunately distance from school does not figure in the PASEC data set and can thus not be tested directly here. 
The effect of GNP per capita (GNP/CAP) would be expected to be positive. However, this positive effect seems to work primarily via the standard of living and school equipment variables already accounted for at levels 1 and 2. When these directly relevant variables are corrected for, no more positive effect can be revealed and the coefficient even turns negative.

The final variable ILLITERACY75 marking the initial state of education countries have to cope with, shows the expected negative and significant effect. Education creates virtuous cycles due to intergenerational externalities, not only within the family, but for the whole society.

\section{Policy options and efficiency considerations}

The above discussion suggests a variety of factors to improve the education system. In order to select those which are most efficient, they have to be compared with respect to their impact and to their cost. However, costs are not always easy to measure, and they sometimes depend on a specific local context. Moreover, the estimated coefficients can only be taken as broad indicators of the size of the effects. Since data cannot be standardized in a meaningful way using $\mathrm{HLM}^{8}$, the coefficients in Table 2 are not directly comparable. However, many of the explaining variables are dummies so that the interpretation of coefficients is straightforward. A detailed definition of all variables is provided in the annex.

Keeping in mind the limitations of the approach, a broad efficiency categorization of different measures can be made. The discussion of these measures will be structured around the four possible reasons for differences in the national efficiency positions outlined in section 2 . First, those factors can be singled out, which do not actually belong to the policy options, but rather represent a given national framework to any policy decision. 
(a) The context and the initial conditions of the education system

Context factors whose change does not really represent a policy option could also be interpreted as measures whose implementation cost tend towards infinity so that they cannot be efficient, however high the benefits would be. Among the significant variables analyzed above, the initial literacy level and the spread of the French language fall into this category. Table 2 already showed that the extremely low literacy levels in 1975 , between not even 10 and $20 \%$, mark a particularly difficult context for the education systems in Burkina Faso, Côte d'Ivoire and Senegal while the low use of the French language in everyday life places Madagascar and again Senegal in a rather unfortunate position. Regression results show that these are indeed serious constraints with respect to learning achievement, at least within the framework of a given French language education system.

(b) Policy options I: Optimizing the mix of educational inputs

Looking at those factors where change seems possible, let us first consider educational inputs in a narrow sense. Here the provision of books clearly dominates in terms of efficiency. At the individual or family level, books are less expensive than television and radio and have a higher effect on learning. Providing access to public libraries - possibly mobile libraries in rural areas can be an even less costly approach and a relevant policy measure. Textbooks, i.e. books adjusted to the learning process at a specific grade level and suitable for use in class, are not more expensive than other books, but have an even greater effect: While having books at home rises scores by 2 to 3 percentage points, having textbooks for math and French rises scores three times as much.

So far, the availability of textbooks in the countries considered here generally remains below $50 \%$ for French and math, in Senegal it is only 35\% (see Table 4). The only exception is Côte d'Ivoire where $70 \%$ of fifth grade students are equipped with textbooks. All in all, while the need is greatest in Senegal, there seems to be considerable scope in all five countries to improve the coverage of textbooks. 
Table 4: Countries' scope for selected policy options

\begin{tabular}{|c|c|c|c|c|c|}
\hline Quality determinant & Burkina Faso & Cameroon & Côte d'Ivoire & Madagascar & Senegal \\
\hline BOOKS & $54 \%(3.3 \%)$ & $50 \%(3.4 \%)$ & $70 \%(2.5 \%)$ & $48 \%(2.9 \%)$ & $35 \%(2.7 \%)$ \\
\hline LOCAL_LANG & $69 \%(4.5 \%)$ & $59 \%(5.1 \%)$ & $38 \%(4.5 \%)$ & $97 \%(1.4 \%)$ & $54 \%(5.1 \%)$ \\
\hline CLASS_SIZE & 64 pupils (2.6) & 53 pupils (2.6) & 36 pupils (1.6) & 37 pupils (1.5) & 55 pupils $(2.1)$ \\
\hline $\begin{array}{l}\text { in double shift } \\
\text { classes }\end{array}$ & 98 pupils (3.0) & 68 pupils (4.8) & 41 pupils (1.0) & 32 pupils (3.5) & 65 pupils (7.8) \\
\hline GENDER_T (\%men) & $71 \%(4.5 \%)$ & $76 \%(4.4 \%)$ & $96 \%(1.9 \%)$ & $38 \%(4.5 \%)$ & $82 \%(3.9 \%)$ \\
\hline ABSENCE (p.month) & 2.2 days $(0.38)$ & 1.8 days $(0.39)$ & 1.3 days $(0.16)$ & 2.3 days $(0.38)$ & 4.8 days $(0.55)$ \\
\hline MOTIVATION & $57 \%(4.9 \%)$ & $56 \%(5.1 \%)$ & $45 \%(4.6 \%)$ & $66 \%(4.4 \%)$ & $41 \%(5.1 \%)$ \\
\hline INSPECTOR & $88 \%(3.3 \%)$ & $88 \%(3.3 \%)$ & $79 \%(3.8 \%)$ & $80 \%(3.6 \%)$ & $84 \%(3.8 \%)$ \\
\hline VOLUNTARY & - & $31 \%(4.7 \%)$ & $1.7 \%(1.2 \%)$ & $14 \%(3.2 \%)$ & - \\
\hline $\begin{array}{l}\text { Note: } \text { The colum } \\
\text { errors in par }\end{array}$ & $\begin{array}{l}\text { show natio } \\
\text { hesis. }\end{array}$ & 1 average $\mathrm{V}$ & les for the & PASEC samp & of fifth graders, standard \\
\hline
\end{tabular}

Sources: CONFEMEN (1999a), own computations.

As compared to the provision of textbooks, the effect of most other classical inputs is rather modest and less clearly significant. Providing a full basic equipment of benches, blackboard, chalk, teacher's desk and chair etc. increases scores by only around 2 percentage points and is comparatively expensive. The distribution of teachers' guides for the subjects they teach brings about even lower learning benefits. However, cost as well are relatively negligible.

There are other interesting measures that can be implemented at almost no cost so that they clearly imply a gain in efficiency. One of these is the employment of teachers in those regions of which they know the language, i.e. generally in their home regions. According to the coefficients in Table 2, this measures would, ceteris paribus, increase students' scores by 2.3 to 3.8 percentage points, i.e. by up to 8.5 percent of average scores. It appears that countries are simply not aware of this positive impact and therefore stick to inefficient policies of teacher allocation to different regional areas. The problem arises in all countries with more than a single national language, i.e. in all countries besides Madagascar (see Table 4). The extreme case is Côte d'Ivoire where only 39\% of fifth grade teachers are able to communicate in the local language. They are purposefully posted in other than their home regions. It seems to be worth considering a revision of this policy.

Moreover, multigrade teaching appears to be generally beneficial and is thus certainly a useful tool in order to avoid inefficiently small classes in remote rural areas on the one hand, and long travel 
distances on the other hand. While the overall regression results strongly encourage the use of this means of class management, they should still be interpreted with some care since "multigrade teaching" can hide very different realities across and even within countries.

With respect to the management of high numbers of students, regression results allow a direct comparison between the impact of double shifts versus increased class size. Since the negative effect of double shift classes has been estimated to be -0.03 , the positive impact of halving the number of students should be at least as high if double shift management is introduced. Given the estimated coefficients of class size, this leads, ceteris paribus, to the following optimization problem:

$$
\begin{aligned}
& y(x / 2)-y(x) \geq 0.03 \quad, y=\text { student achievement, } x=\text { class size } \\
& -0.003437 \cdot(x / 2)+0.000028 \cdot\left(3 / 4 x^{2}\right) \geq 0.03 \\
& \Rightarrow \quad x \geq 97
\end{aligned}
$$

This means that below a class size of about 100 students, double shift classes are generally inefficient.

The critical class size was calculated here assuming the feasibility of double shifts without additional cost. In reality, however, double shift management often significantly increases cost since teachers have to be paid overtime rates for additional work hours. This further increases the minimum number of pupils for double shift classes to be an efficient option. The average class size in the PASEC sample does not suggest much scope for this management tool. However, due to the considerable variance of class size within countries, in some cases, double shifts might still be appropriate. Looking at actual student numbers in double shift classes, it becomes clear that in particular Madagascar tends to overuse this management option. Table 4 shows that on average, one shift consists of only 31 students. Total class size would thus not have exceeded about 60 pupils. Conversely, Burkina Faso might think about a more frequent use of double shift management. 
Another important question is from which number of students onwards it might generally make sense to separate students into two different classes. If double shifts are avoided, the right hand side of the above optimization problem (1) becomes zero. It turns out that in this case, separating classes leads to improved learning from a minimum of 82 students onwards. However, even at this level, a small improvement in quality is paid the relatively high price of an additional teacher salary and the rent of an additional classroom. It thus appears to be more efficient to offset losses in quality by other, less costly improvements (for instance the provision of textbooks). By these means, the anyway rather limited tradeoff between quantity and quality can be handled in an efficient manner.

Another relevant option to reduce the pressure of high numbers is to introduce a more moderate repetition policy. Extremely high repetition rates (already presented in Table 2) keep students in the education system for too long and inflate student numbers without any sustainable benefit in terms of achievement. Repetition should be an exception and not the rule as it currently seems to be the case. PASEC countries might orient themselves at the rates in anglophone Africa which are around $7 \%$ instead of $23 \%$ in francophone Africa (and 27\% in the PASEC sample of fifth graders; CONFEMEN 2000, p. 52).

The efficiency ranking of the remaining factors is more difficult. Many of them have a marked effect on learning achievement, but can also imply high cost. In particular, teachers own educational attainment has an important effect on students' learning, while, at the same time considerably increasing cost. There are opportunity cost for the non-used human capital while they continue their studies, and once they start teaching, well educated teachers get considerably higher salaries. The overall effect is thus difficult to evaluate.

Others factors have a less pronounced effect, but appear to be useful if additional objectives like poverty reduction are taken into account. The variable of regular meals, for instance, only has a relatively small impact on learning, and costs for setting up and running school canteens are very high. Alternative solutions like the regular provision of smaller snacks of high nutritional value or 
of a glass of milk can be much cheaper. However, they might still not be considered a high priority in order to rise education quality. At the same time, it is clear that these programs would be highly beneficial to reduce malnutrition as such, and in order to rise poor children's enrolment. Expenditure can be reduced if the programs are targeted on poor children, or at least, poor areas. The example of Peru shows that this is possible. Younger (2000) identifies the clearly redistributive effect of the country's "vaso de leche" (glass of milk) program.

Finally, besides the general quality and quantity concerns, there might be the objective to specifically promote girls. This could be motivated by equality concerns or by the recognition of the positive externalities of women's education (see e.g. Barrera, 1990; Wolfe and Behrman, 1984; Thomas, Strauss and Henriques, 1991; and Schultz, 1993). In this case, it appears to be useful to employ more female teachers and to encourage them to choose this career. This does not imply any extra cost. Currently, apart from Madagascar, pupils are predominantly taught by male teachers. The most extreme case is Côte d'Ivoire where only $4 \%$ of fifth grade teachers are women (see Table 4). One might also think about the introduction of single sex classes so that both groups of children could be taught by a teacher of the same gender. While this measure would be very expensive in remote areas with few students, it can be implemented at no cost in bigger urban schools where students of the same grade level are anyway split into different classes.

(c) Policy options II: Increasing the capacity to transform inputs into effective student learning Factors considered here are mainly of motivational and institutional nature. One major aspect is how to increase teachers' incentives for effective teaching. Table 4 shows that Senegal faces the greatest problems of teacher motivation and high absenteeism. Senegal's fifth grade teachers are absent from work more than twice as much as their colleagues in all other countries. According to the directors, the major problem seems to be the need for teachers to collect their salaries in a faraway place. Concerning general motivation as expressed through the percentage of teachers who 
would be willing to choose the teaching profession again, differences across countries are less significant. However, since teachers' motivation has a considerable impact on student achievement, it may be worth investigating which factors influence this variable.

As noted already in section 2, two very important incentive related variables are the visit of the school inspector and work under a so called "voluntary" i.e. non civil servant contract. While inspectors already come to $80 \%$ to $90 \%$ of schools in all countries, teachers' employment on non civil servant contracts is very unequally spread across countries. In Burkina Faso, Senegal and Côte d'Ivoire, voluntary teachers are very rare, and in the first two countries, they do not figure at all in the sample of fifth graders. In principle, voluntaries can be employed in public as well as in private schools. Since this type of contract clearly encourages teachers' responsiveness and effort, its more frequent use can be strongly recommended.

(d) Policy option III: Reevaluating the cost of input factors

While it remains to be clarified why expenditure per student shows a positive effect on achievement once educational input variables are corrected for, this effect does not seem to depend on teachers' salaries. This most important factor determining the cost of educational input does not show any direct effect on learning achievement. The salary level does not seem to influence education indirectly via the motivation variable either, since it is particularly low in Madagascar and Cameroon where motivation according to Table 4 is comparatively high. Relatively high general salary levels might thus be one major reason for the low efficiency positions of Burkina Faso, Senegal and Côte d'Ivoire. Unfortunately, a detailed analysis of this important question is beyond the scope of this paper since salary data are so far not available at teacher level. 


\section{Conclusions}

All in all it can be concluded that there is a wide variety of measures which can be carried out to increase the efficiency of education spending. While some, such as the provision of textbooks and the employment of a higher number of teachers on flexible non civil-servant contracts, should be a clear priority for all countries and all schools, other measures require a thorough consideration of the specific national or even local context in which they would be carried out. Management of high student numbers is a matter in case. Since increased class size shows no or an only a very moderate negative impact on student achievement up to a relatively high number of students, separating classes is generally not necessary. Only if class size rises above 100 pupils, double shift management should be considered. Moreover, the ranking of priorities obviously depends on whether educational objectives are linked with other objectives such as poverty reduction and gender equality. Finally, it appears that teacher salaries might be an important factor to explain the different efficiency levels of education spending across countries. Unfortunately, a more detailed analysis of this factor cannot be carried out on the basis of the currently available data. 


\begin{tabular}{|c|c|c|}
\hline \multicolumn{3}{|c|}{ Appendix: Definitions and sources* of regression variables } \\
\hline (level 1) & \\
\hline FRENCH & \multicolumn{2}{|l|}{ Dummy (French spoken at home $=1$, not spoken $=0$ ) } \\
\hline LIT_P & \multicolumn{2}{|c|}{$(0,1,2)$ Both parents literate $=2$, mother or father literate $=1$, both illiterate $=0$} \\
\hline LIBRARY & \multicolumn{2}{|c|}{ Dummy (student can use books at home $=1$, can't use $=0$ ) } \\
\hline MEDIA & \multicolumn{2}{|c|}{$\begin{array}{l}(0,1,2) \text { Availability at home of: radio and television }=2 \text {, radio or television }=1 \text {, neither of } \\
\text { the two }=0\end{array}$} \\
\hline MEALS & \multicolumn{2}{|c|}{$\begin{array}{l}(3,2,1,0) \text { Regular breakfast, lunch and dinner }=3 \text {, only two regular meals }=2 \text {, only one }=1 \text {, } \\
\text { none }=0\end{array}$} \\
\hline REPEAT & \multicolumn{2}{|c|}{ Dummy (student repeating $5^{\text {th }}$ grade $=1$, not repeating $=0$ ) } \\
\hline REPEAT2 & \multicolumn{2}{|l|}{ Number of grades repeated before the $5^{\text {th }}$ grade } \\
\hline HIGHAGE & \multicolumn{2}{|l|}{ Dummy (age $>11=1$, age $<=11=0)$} \\
\hline GENDER & \multicolumn{2}{|l|}{ Dummy (boy=1, girl=0) } \\
\hline (level 2) & & \\
\hline EDUCATION & \multicolumn{2}{|c|}{$\begin{array}{l}(0,1, \ldots, 6) \text { Teacher's educational attainment (below } 6^{\text {th }} \text { grade }=0,6^{\text {th }} \text { or } 7^{\text {th }} \text { grad }=1,8^{\text {th }} \text { or } \\
9^{\text {th }} \text { grade }=2,10^{\text {th }} \text { or } 11^{\text {th }} \text { grade }=3 \text {, baccalauréat }=4 \text {, bac. }+1 \text { or } 2 \text { years of tertiary } \\
\text { education }=5,3 \text { years or more of tertiary education }=6)\end{array}$} \\
\hline TRAINING & \multicolumn{2}{|c|}{ Number of training courses followed per year during the last five years } \\
\hline LOCAL_LANG & \multicolumn{2}{|c|}{ Dummy (teacher speaks local language $=1$, does not speak $=0$ ) } \\
\hline FRENCH_T & \multicolumn{2}{|c|}{ Dummy (teacher always or often speaking French outside classes $=1$, else $=0$ ) } \\
\hline EXPERIENCE & \multicolumn{2}{|c|}{ Number of years of teaching experience } \\
\hline ACTIVITIES & \multicolumn{2}{|c|}{$\begin{array}{l}\text { Dummy (teacher follows other non teaching/school related activities, such as farming, } \\
\text { shop-keeping etc. }=1 \text {, no such activities }=0 \text { ) }\end{array}$} \\
\hline TUITION & \multicolumn{2}{|c|}{ Dummy (teacher gives private tuition $=1$, does not $=0$ ) } \\
\hline ABSENCE & \multicolumn{2}{|c|}{ Number of days teacher was absent from school during the last month $(\max =25)$} \\
\hline MOTIVATION & \multicolumn{2}{|c|}{ Dummy (teacher would again choose the same profession $=1$, would not $=0$ ) } \\
\hline EXCHANGE & \multicolumn{2}{|c|}{ Dummy (teacher often (or very often) asks his colleagues for advice $=1$, else $=0$ ) } \\
\hline CORRECTION & \multicolumn{2}{|c|}{$\begin{array}{l}\text { Dummy (teacher considers the correction of copy-books during class hours as one of his } \\
\text { four major tasks }=1 \text {, else }=0 \text { ) }\end{array}$} \\
\hline EQUIPMENT & \multicolumn{2}{|c|}{ Dummy (basic equipment available $=1$, not available $=0$ ) } \\
\hline & \multicolumn{2}{|c|}{$\begin{array}{l}\text { "Basic equipment" includes: teacher's desk, usable blackboard, seats and desks for all } \\
\text { students, white chalk, pencils and copy-books or slates for at least } 75 \% \text { of the students. }\end{array}$} \\
\hline BOOKS & \multicolumn{2}{|c|}{$\begin{array}{l}\text { Share of students equipped with textbooks, average for math and French. When data } \\
\text { were available for only one subject, the share in this subject was used as a proxy for the } \\
\text { overall share. }\end{array}$} \\
\hline GUIDE & \multicolumn{2}{|c|}{$\begin{array}{l}(0,1,2) \text { Teacher's manual for math and French available }=2 \text {, for one subject }=1 \text {, for none } \\
\text { of the two }=0\end{array}$} \\
\hline URBAN & Dummy (urban school=1, rural school=0) & \\
\hline CLASS_SIZE & Average number of students attending classes & \\
\hline DOUBLESHIFT & the same room at different times of the day $=1$, else $=$ & \\
\hline MULTIGRADE & $\begin{array}{l}\text { Dummy (students of several grades together in one c } \\
\text { classes using }\end{array}$ & ass $=1$, else $=0$ ) Dummy (several \\
\hline ASSOCIATION & $\begin{array}{l}\text { Sum of activity level of different types of school con } \\
\text { very active }=1 \text {, active }=0.5 \text {, slightly active }=0.1 \text {, not ac }\end{array}$ & $\begin{array}{l}\text { mittees and associations (for each: } \\
\text { ve at all=0) }\end{array}$ \\
\hline PILOT_PGR & $\begin{array}{l}\text { Dummy (school participates in a special program }=1 \text {, } \\
\text { pilot program, an exchange program with another (fo } \\
\text { project etc. }\end{array}$ & $\begin{array}{l}\text { lse=0). This special program can be a } \\
\text { eign) school, an NGO financed }\end{array}$ \\
\hline INSPECTOR & Dummy (visit of the inspector since the beginning of & he year $=1$, else $=0$ ) \\
\hline VOLUNTARY & Dummy (teacher is no civil servant $=1$, civil servant= & \\
\hline UNION & Dummy (teacher is union member $=1$, non member $=$ & \\
\hline GENDER_T & Dummy (male teacher $=1$, female teacher $=0$ ) & \\
\hline WOMENS_GP & Dummy (director is in contact with women's group & 1$, else $=0)$ \\
\hline (level 3) & & \\
\hline EXP/STUD & $\begin{array}{l}\text { Public expenditure for primary education per } \\
\text { student, } 1985 \text { - } 1995 \text { averages, in const. } 1995 \text { US\$; } \\
\text { in Senegal } 1996 \text { data were used as an estimate of } \\
\text { missing } 1995 \text { data }\end{array}$ & Source: World Bank (1999) \\
\hline GNP/CAP & GNP per capita in current US\$ (PPP), 1995 & Source: World Bank (1999) \\
\hline ILLITERACY(75) & 1975 illiteracy rate (in \%) & Source: World Bank (1999). \\
\hline & $\begin{array}{l}\text { For Madagascar the } 1975 \text { illiteracy rate was } \\
\text { estimated to lie around } 60 \% \text {. }\end{array}$ & $\begin{array}{l}\text { Estimations for Madagascar are } \\
\text { based on various editions of the } \\
\text { UNESCO Statistical Yearbook } \\
\text { (see UNESCO, 1998). }\end{array}$ \\
\hline
\end{tabular}

* If not otherwise indicated, the source is CONFEMEN (1999a). 


\section{REFERENCES}

African Development Bank (1998). Rapport sur le développement en Afrique 1998, Abidjan.

Barrera, A. (1990). The Role of Maternal Schooling and its Interaction with Public Health Programs in Child Health Production, Journal of Development Economics, 32(1), pp. 69-91.

Bernard, J.-M. (1999a). Les Enseignants du primaire dans Cinq Pays du Programme d'Analyse des Systèmes Educatifs de la CONFEMEN : Le Rôle du Maître dans le Processus d'Acquisition des Élèves, Report for the Working Group on the Teaching Profession, ADEA, French Section, Paris.

Bernard, J.-M. (1999b). Les Enseignants du Primaire dans Cinq Pays du Programme d'Analyse des Systèmes Educatifs de la CONFEMEN : Caractéristiques, Conditions de Travail et Représentations, Report for the Working Group on the Teaching Profession, ADEA, French Section, Paris.

Bryk, A.S., \& Raudenbush, S.W. (1992). Hierarchical Linear Models: Application and Data Analysis Models, Advanced Qualitative Techniques in the Social Sciences No.1, London: Sage.

Cohen, J., \& Baldi, S. (1998). The Hazards of School Centering in Educational Applications of Hierarchical Linear Models, mimeo, American Institutes for Research, Pelavin Research Centre, Washington D.C.

CONFEMEN (2000). Actes de la 49e session ministérielle de la CONFEMEN, Bamako: CONFEMEN.

CONFEMEN (1999a). PASEC : Les facteurs de l'efficacité dans l'enseignement primaire: données et résultats sur cinq pays d'Afrique et de l'Océan Indien, CD-ROM.

CONFEMEN (1999b). Les facteurs de l'efficacité dans l'enseignement primaire: Les résultats du programme PASEC sur neuf pays d'Afrique et de l'Océan indien, Rapport de synthèse du Programme d'Analyse des Systèmes Educatifs de la CONFEMEN (PASEC), Dakar: CONFEMEN.

CONFEMEN (1999c). L'enseignement primaire en Côte d'Ivoire, investigations et diagnostics pour l'amélioration du système éducatif, in: CONFEMEN (1999a). PASEC : Les facteurs de l'efficacité dans l'enseignement primaire : données et résultats sur cinq pays d'Afrique et de l'Océan Indien, CD-ROM.

CONFEMEN (1999d). L'enseignement primaire au Cameroun, investigations et diagnostics pour l'amélioration du système éducatif, in: CONFEMEN (1999a). PASEC : Les facteurs de l'efficacité dans l'enseignement primaire : données et résultats sur cinq Pays d'Afrique et de l'Océan Indien, CD-ROM.

CONFEMEN (1999e). L'enseignement primaire au Burkina Faso, investigations et diagnostics pour l'amélioration du système éducatif, in: CONFEMEN (1999a). PASEC : Les facteurs de l'efficacité dans l'enseignement primaire : données et résultats sur cinq pays d'Afrique et de l'Océan Indien, CD-ROM.

CONFEMEN (1999f). Les facteurs de l'efficacité dans l'enseignement primaire : les résultats du programme PASEC sur huit pays d'Afrique, in: CONFEMEN (1999a). PASEC: Les facteurs de l'efficacité dans l'enseignement primaire : données et résultats sur cinq pays d'Afrique et de l'Océan Indien, CD-ROM.

CONFEMEN (1999g). Faut-il modifier la politique de redoublement ? Les cas du Burkina Faso, de la Côte d'Ivoire et du Sénégal, in: CONFEMEN (1999a). PASEC : Les facteurs de l'efficacité dans l'enseignement primaire : données et résultats sur cinq pays d'Afrique et de l'Océan Indien, CD-ROM.

Dempster, A., Rubin, D.B. \& Tsutakawa, R.K. (1981). Estimation in Covariance Components Models, Journal of the American Statistical Association 76(3/4), pp. 341-353.

Glewwe P., \& Jacoby, H. (1994). Student Achievement and Schooling Choice in Low-Income Countries Evidence from Ghana, Journal of Human Ressources 29(3), pp. 843-864. 
Goldstein, H. (1999). Multilevel Statistical Models, Kendal's Library of Statistics 3, Internet Edition. http://www.arnoldpublishers.com/support/goldstein.htm.

Hanushek, E. A. (1998). The Evidence on Class Size, Occasional Paper No. 98-1, W. Allen Wallis Institute of Political Economy, University of Rochester.

Hanushek, E. A., Kain, J.F., \& Rivkin, S.G. (1999). Do Higher Salaries Buy Better Teachers, Paper Presented at the Annual Meeting of the American Economic Association, 3-5 Janvier 1999, New York.

Harbison, R., \& Hanushek, E.A. (1992). Educational Performance and the Poor: Lessons from Rural Northeast Brazil, Oxford: Oxford University Press for the World Bank.

Jamison, D.T. (1986). Child Malnutrition and School Performance in China, Journal of Development Economics 20(2), pp 299-309.

Jarousse, J., \& Mingat, A. (1993). L'école primaire en Afrique, Paris: L’Harmattan.

Lockheed, M.E. \& Longford, N.T. (1990). A Multilevel Model of School Effectiveness in a Developing Country, World Bank Discussion Paper No. 69, World Bank, Washington.

Maclure, Richard (1997) Overlooked and Undervalued - A Synthesis of ERNWACA Reviews on the State of Education Research in West and Central Africa, Report for the SARA Project of USAID, Washington D.C.

Martorell, R., \& Habicht, J. (1986). Growth in Early Childhood in Developing Countries, Human Growth: A Comprehensive Treaty, Vol. 3 Methodology, Ecological, Genetic and Nutritional Effects on Growth, New York: Plenum Pub.

Michaelowa, K. (2000). Dépenses d'Éducation, Qualité de l'Éducation et Pauvreté - l'Exemple de Cinq Pays d'Afrique Francophone, OECD Development Centre Technical Paper No. 157, Paris.

Mingat, A., \& Suchaut, B. (1998). Une analyse économique comparative des systèmes éducatifs africains, rapport réalisé pour le Ministère Français des Affaires Etrangères, Coopération et Francophonie, Paris.

Minter-Hoxby, C. (1996). How Teachers' Unions Affect Education Production, Quarterly Journal of Economics 111(3), pp. 671-718.

Moock, R., \& Leslie, J. (1986). Childhood Malnutrition and Schooling in the Terai Region of Nepal, Journal of Development Economics 20(1), pp. 33-52.

Morrisson, C., Guilmeau, H., \& Linskens, C. (2000). Une estimation de la pauvreté en Afrique subsaharienne d'après les données anthropométriques, OECD Development Centre Technical Paper No. 158, Paris.

Mosha, H.J. (1988). A Reassessment of Primary Education Quality in Developing Countries : Emerging Evidence from Tanzania, International Review of Education 34, pp. 17-45.

Naumann, J., \& Wolf, P. (2001). Recherche empirique de la performance de systèmes africains d'enseignement primaire - critique et réanalyse de données PASEC pour le Sénégal, Working Paper, faculty for education and social sciences, Institute for General Education, Münster (Germany)

Pritchett, L., \& Filmer, D. (1999). What Education Production Functions Really Show: A Positive Theory of Education Expenditures, Economics of Education Review 18, pp. 223-239. 
Proteau, L. (1998). Itinéraires précaires et expériences singulières. La scolarisation féminine en Côte d'Ivoire. In M.-F. Lange (Ed.), L'école et les filles en Afrique - scolarisation sous conditions (pp. 27-71). Paris: Karthala

Ross, K. (1998) (Ed.). SACMEQ Policy Research, The Quality of Education : Some Policy Suggestions Based on a Survey of Schools, (Report No. 1: Mauritius, by Dhurmbeer Kulpo ; Report No. 2: Namibia, by Friedhelm Voigts; Report No. 3: Zimbabwe, by Thomas Machingaidze, Patrick Pfukani and Sibangani Shumba ; Report No. 4: Zanzibar, by Sebtuu Nassor \& Khadija Ali Mohammed, Report No. 5: Zambia, by Manasseh Nkamba \& Joe Kanyika) Paris: IIEP.

Schultz, T.P. (1993). Investments in the Schooling and Health of Women and Men, Journal of Human Ressources 28(4), pp 694-734.

Tan, J., Lane, J. \& Coustère (1997). Putting Inputs to Work in Elementary Schools: What Can Be Done in the Phillipines?, Economic Development and Cultural Change 45(4), pp 857-879.

Tansel, A. (1997). Schooling Attainment, Parental Education, and Gender in Côte d'Ivoire and Ghana, Economic Development and Cultural Change 45(4), pp. 825-856.

Thomas, D., Strauss, J., \& Henriques, M.-H. (1991). How Does Mother's Education Affect Child Height?, Journal of Human Ressources 26(2), pp 183-211.

UNESCO (1998). Statistical Yearbook, Paris.

UNESCO-Santiago (1998). Primer Estudio Internacional Comparativo, Santiago.

UNESCO/UNICEF (1995a). Suivi permanent de l'éducation pour tous - Mali, Bamako.

UNESCO/UNICEF (1995b). Projet de suivi permanent de l'éducation pour tous - évaluation du niveau d'acquisition des élèves de la quatrième année fondamentale, rapport du Maroc, Rabat.

UNICEF (1999). The State of the World's Children - Education, New York.

Wolfe, B.L., \& Behrman, J.R. (1984). Determinants of Women's Health Status and Health Care Utilization in a Developing Country : A Latent Variable Approach, Review of Economics and Statistics, 66(4), pp. 696703.

World Bank (1999). World Development Indicators 1999, CD-ROM.

Wößmann, L. (2000). Schooling Resources, Educational Institutions, and Student Performance: The International Evidence, Kiel Working Paper No. 983, Kiel: Kiel Institute of World Economics.

Younger, S. (2000). The Incidence of Public Services and Subsidies in Peru, mimeo, OECD Development Centre, Paris. 


\section{Notes}

1 Original French names: PASEC: Programme d'Analyse des Systèmes Educatifs des Pays de la CONFEMEN; CONFEMEN: Conférence des Ministres de l'Éducation des Pays ayant le Français en Partage.

Data and first analytical reports are available on CD-Rom free of charge from the CONFEMEN (CONFEMEN, 1999a). If interested please contact the managing team at pasec@telecomplus.sn. The surveys were carried out between 1995 and 1998. Similar surveys were initiated for a couple of English speaking sub-Saharan African countries by the Southern Africa Consortium for Monitoring Educational Quality (SACMEC) and for Latin-American countries by the "Laboratory Project" of UNESCO-Santiago. For an overview and initial results see Ross (1998) and UNESCO-Santiago (1998) respectively. However, both SACMEC and UNESCO-Santiago data were initially put under embargo and are not yet available for international research.

${ }^{2}$ It can be argued that the commonly used term "education production function" is actually incorrect since it implies an efficient use of all factors which cannot be observed in the education sector. See Pritchett and Filmer (1999, p. 224f.).

${ }^{3}$ The PASEC sample contains only one fifth grade class in each school. The terms "school" and "class" are therefore used without distinction as far as the identification of level 2 is concerned.

${ }^{4}$ For more details concerning the construction of multi-level HLM, see Bryk, Raudenbush (1992) or Goldstein (1999).

${ }^{5}$ The same problem is known from econometric analysis of panel data with random effects. In fact, panel models represent a specific sub-group of HLM, with time series observations nested within individuals.

${ }^{6}$ For complementary information, helpful to understand the technical annex of Bryk, Raudenbush (1992), see Dempster, Rubin, Tsutakawa (1981).

${ }^{7}$ In the international literature, there is a highly controversial debate on whether teachers' salaries influence learning outcomes or not. See e.g. UNICEF (1999, p. 39) and Maclure (1997, p. 52) for the first, and Hanushek, Kain and Rivkin (1999) and Mingat, Suchaut (1998) for the second position.

${ }^{8}$ For a discussion why standardization is generally misleading in HLM, see Cohen and Baldi (1998). 